\title{
THEORETICAL FRAMEWORK FOR SUSTAINABILITY, CORPORATE SOCIAL RESPONSIBILITY AND CHANGE MANAGEMENT
}

\author{
SUSANA DIAZ-IGLESIAS*, ALICIA BLANCO-GONZALEZ AND CARMEN ORDEN-CRUZ \\ Universidad Rey Juan Carlos. Faculty of Legal and Social Science. Business Economics Department. Paseo Artilleros s/n, \\ 28032 Madrid, Spain.
}

*Corresponding author: susana.diaz@urjc.es

Submitted final draft: 5 December 2020 Accepted: 7 January $2021 \quad$ http://doi.org/10.46754/jssm.2021.08.025

\begin{abstract}
The purpose of this paper is to construct a theoretical framework on the origins of three concepts, sustainability, corporate social responsibility (CSR), and change management, to have a clear vision on their evolution and understand whether there are existing relationships between them. The main findings are that there is a relationship between the three concepts. The private sector implements Sustainable Development Goals through conducting CSRs. CSR strategies create a competitive advantage that positively impacts business results. Implementing CSR as a strategy involves a series of changes not only at the managerial level, but also at the strategic level, according to stakeholders' interests. Thus, efficient change management when developing CSR strategies to implement sustainability goals can maximise the chances of success in this process. One important implication of this issue is the need to develop best practices and models to facilitate change management in the implementation of CSR strategies in organisations. There should be more regulations and guidelines on the subject, so more companies could use it and start developing CSR reports.
\end{abstract}

Keywords: Sustainability, corporate social responsibility (CSR), change management.

\section{Introduction}

Organisations today are searching continually for competitive advantages to adapt to changing situations. Although there are numerous studies on sustainability, corporate social responsibility (CSR) and change management (CM), the connection between the three concepts remains largely unexplored. This paper aims to narrow this research gap. By developing a theoretical framework, this paper provides a foundation for future empirical research.

The United Nations (UN) is the prominent international organisation in global sustainable development. In its 2015 summit, "Transforming our World: The 2030 Agenda for Sustainable Development", member states established a list of 17 Sustainable Development Goals. This challenge has become one of the priorities of the world agenda. The way in which companies integrate these development goals into their business models, strategies and policies is crucial to understand the achievements obtained. To accomplish the challenge of implementing
CSR into the business world, changes must occur not only at the managerial level, but also at the strategic level, in line with the stakeholders' interests.

The objective of this paper is to analyse the insight of $\mathrm{CM}$ in organisations in the evolution of the concept of sustainability, and more specifically, corporate sustainability. This paper traces the evolution of the three constructs and the classification of its typologies and existing models to reach a global vision of the importance for companies to have good CM when implementing sustainability in their core business models. A wide bibliographic review of academic literature and reports used by international institutions was conducted.

Following this introduction, the paper is organised as follows: Section 2 discusses the evolution of the concept of sustainability in academic literature, highlighting key milestones according to UN conferences and summits. Section 3 presents different views of the classification of sustainability. Section 4 
introduces the concept ofCSR. Section 5 analyses Organisational CM regarding sustainability. The discussion in section 6 presents the conclusions, and references are included in section 7 .

\section{The Evolution of the Concept of Sustainability}

Much has been written about economic growth, social equality and sustainability in the last 180 years (Dyllick \& Hockerts, 2002). Most authors agree that the origin of the concept of "sustainability" took place in the 1960s, when the environmental movement grew due to concerns about social issues and the impact of the traditional business models on the global ecology (Millar, Hind \& Magala, 2012). It was implicitly considered as an objective in 1968 in the "Biosphere conference" held in Paris and, in the same year, in the Conference on the Ecological Aspects of International Development was convened, near Washington DC, by the Conservation Foundation and the Center for the Biology of Natural Systems, Washington University, St. Louis, Missouri (Caldwell, 1984).

The very first time the term "sustainable development" was included in a publication was in 1713, when the German term "nachhaltende nutzung" (sustainable use), was explained by von Carlowitz and von Rohr (Waas, Hugé, Verbruggen, \& Wright, 2011). Following Wilderer (2007), the concept of sustainable forest management was defined as "maintaining economic stability is achieved when, per unit of time, an amount trees are cut down as the same amount are growing."

According to Mebratu (1998), the main precursor of the concept of "sustainable development" is Thomas Malthus (1766-1834), who, together with David Ricardo (1772-1823), developed the "theory of environmental limits thinking". For Malthus, the fixed amount of land available (absolute scarcity limit) meant that as the population grew, diminishing returns would reduce the per capita food supply. The standard of living would be forced down to a subsistence level, and the population would cease to grow. He was the first economist to foresee the limits to growth caused by resource scarcity. Malthus said the vices and misery that plague society are not due to evil human institutions, but due to the fecundity of humans. This led to his "theory of population". According to Malthus's theory, unchecked population increases geometrically, while subsistence increases arithmetically at best.

In the 1970s, a challenge arose to the conventional consensus of economic development thinking, as there was an important emphasis placed on improving the basic needs of the poor, known as the "basic needs strategy" within a sustainable development approach. This means that real improvement in Third World countries needs a strong commitment to formulating and implementing environmentally sustainable strategies in the long term, and that they be consistent with social values, while preserving the environment and protecting the rational use of resources (Barbier, 1987). At that time, the UN became the principal initiator and driver of sustainable development at the international level. Studying the milestone dates of key conferences, conventions and summits offers insight into the evolution of the term and its history.

The first milestone was the international conference on the Human-Environment, United Nations Conference on the Human Environment (UNCHE; 1972), which took place in Stockholm. This was the beginning of the emerging concepts that evolved in the following years to "environment and development", "development without destruction" and "environmentally sound development", as well as the term "eco-development" that later appeared in the United Nations Environment Program review in 1978. At this time, the environmental and the developmental ideas as a common outlook became internationally recognised (Mebratu, 1998). Also addressed at the Stockholm conference were the human impacts on the environment to reconcile economic development with environmental quality, aspects that were considered incompatible until that moment (Caldwell, 1984). 
After the Stockholm conference, there was a scientific consensus on ecological imbalances due to human activities and the damage suffered by nature, which contributed to the development of the term "sustainable development" (Mebratu, 1998). An extension of the terminology began to appear in the early and mid-1980s, where environmental and social issues were linked. New concepts were later linked to environmental sustainability, such as existing discourses on climate change and sustainable society development, and thinking on the short-term evolution of a different society (Cohen, Demeritt, Robinson, \& Rothman, 1998). According to this vision, a more stationary population uses energy more efficiently, and the economy is fuelled with renewable sources of energy (Brown, 1981).

Another milestone was the UN World Commission on Environment and Development (WCED) in 1983, which attempted to examine the economic and ecological crisis, and served as the scenario to coin the concepts of sustainability and sustainable development and to promote the quality of life for present and future generations. Its report was called "Our Common Future. A global agenda for change," and is also recognised as "The Brundtland Report". It was elaborated in 1987 and introduced the definition of sustainable development that is accepted until now: "Progress that meets the needs of the present without compromising the ability of future generations to meet their own needs" (WCED, 1987). It was a major political turning point and gave international recognition to the need for an ecologically sustainable economy (Caldwell, 1984). The statement does not include the definition of development, but it specifies that sustainable means not impoverishing the future (Daly, 1996).

According to Kirkby, O'keef, and Timberlake, (1995), the conceptual definition presented in "The Brundtland Report" establishes the structure for debate for the years to come. It contains two key concepts: the concept of "needs", in particular the essential needs of the world's poor, to which overriding priority should be given, and the idea of limitations imposed by the state of technology and social organisation (Mebratu, 1998).

From another point of view, the idea of "sustainable development" became dominant for less developed countries (the South), based on the concept of "steady-state economy" and "stationary state", but not for mature, developed countries (the North). According to Daly (1996), the critical issue is for the North to attain sustainability, using a level of resources that affords quality of life for the population and is within the regeneration and environmental waste absorption in a sustainable way

Additional steps were subsequently added to the definition of the key goals of sustainability: to live within our ecological limits, to achieve social justice and to foster economic and social progress (Mader, Scott \& Razar, 2013). The three problems are interconnected, that is, none can be solved without solving the other two. This was accepted by politicians, NGOs and business leaders in the United Nations Conference on Environment and Development (UNCED) in 1992), the Earth Summit, also known as "Rio Conference" (Keating, 1993). Sustainable development and the neoliberal ideology were articulated together at this conference, defended by dynamic economic development and access to markets, thus fundamentally linking the idea of "free trade" with environmental protection (Tulloch, 2013). The production of international documents, such as the Agenda 21 or the Rio Declaration, left a great legacy. Most importantly, preparation for the conference began in 1989 and included the participation of major stakeholders of all levels in most countries, bringing the concept of "sustainable development" to every part of the world (Mebratu, 1998).

In the mid-1990s, some authors pointed out that the dialectical concept of sustainable development was accepted as political consensus, but due to different interpretations, as described by Goldin and Winters (1995), the concept remained "elusive". According to Daly (1996), it was "still dangerously vague," and a 
breeding ground for disagreements. According to Mebratu (1998), the lack of definition did not help in achieving the desired changes. In his foreword to the United Nations Conference (1997), (Rio+5 Conference), Kofi Annan mentioned that "the Agenda for Development, was one of the most far-reaching agreements on the central issue of development ever attained by the international community." These words provided a comprehensive framework for international cooperation on development based on partnerships, rather than competing interests. The given definition of sustainability captured three dimensions in the Agenda for Development, the social, the economic and the environmental: "Development is a multidimensional undertaking to achieve a higher quality of life for all people. Economic development, social development and environmental protection are interdependent and mutually reinforcing components of sustainable development."

Given that modern science understands that the logical essence of the meaning of sustainability is living in harmony with nature and with one another (Mebratu, 1998), sustainability may also be defined as ensuring well-being, indefinitely if possible, and being aware of the natural resources, environmental quality and capital we are leaving for future generations (Kuhlman \& Farrington, 2010). Material earnings do not guarantee human well-being (Gibson, 2001), although on one hand, for some authors such as Solow (1992), some natural resources loss could be accepted, compensating it with increasing the capital for future generations. On the other hand, others assert that capital cannot substitute for natural resources and sustainability is a way of protecting the resources essential for survival (Daly, 1996).

In September 2000, the United Nations Millennium Summit took place at the United Nations headquarters. During the summit, global leaders set out 8 time-bound targets to reduce extreme poverty, known as the Millennium Development Goals. Also included in the Millennium Declaration was a statement of values, principles and objectives for the international agenda for the 21 st century. It also set deadlines for many collective actions. The participants of the summit resolved to adopt a new ethic of conservation and stewardship with regard to environmental protection.

Another milestone was the United Nations World Summit on Sustainable Development, held in Johannesburg in September 2002. The goal of the summit was to examine the implementation of the resolutions made at the conference in Rio, with a particular focus on Agenda 21. The signed declaration contains a set of political commitments by heads of state and government to implement proposals related to sustainable development.

Ten years later, in June 2012, the United Nations Conference on Sustainable Development (Rio+20 "The Future we want") took place in Rio de Janeiro. The result was a document detailing practical measures for implementing sustainable development. Member states also decided to launch a process to develop a set of Sustainable Development Goals (SDGs), which was built upon the Millennium Development Goals and converged with the post-2015 development agenda.

An Open Working Group was formed to further this agenda. And after more than a year of negotiations, they presented their recommendations for 17 sustainable goals (see Table 1). The new agenda they created, "Transforming our World: The 2030 Agenda for Sustainable Development," was signed during the Sustainable Development Summit, which took place in 2015 in New York. There are 17 Sustainable Development Goals with 169 targets, in contrast to the 8 Millennium Development Goals with 21 targets, to help countries monitor their contributions to the 17 SDGs (see Table 1). These goals are the guide and centre of the global political agenda to gain the support of all organisations and individuals to create a more just, responsible and sustainable world (Guijarro \& Poyatos, 2018). 
Table 1: The sustainable development goals

\begin{tabular}{|c|c|c|}
\hline UN_SDGs & Definition & Description \\
\hline UN_SDG_1 & No poverty & End poverty in all its forms everywhere. \\
\hline UN_SDG_2 & Zero hunger & $\begin{array}{l}\text { End hunger, achieve food security, and improve nutrition and } \\
\text { promote sustainable agriculture. }\end{array}$ \\
\hline UN_SDG_3 & $\begin{array}{l}\text { Good health and well- } \\
\text { being }\end{array}$ & Ensure healthy lives and promote well-being for all at all ages. \\
\hline UN_SDG_4 & Quality education & $\begin{array}{l}\text { Ensure inclusive and equitable quality education and promote } \\
\text { lifelong learning opportunities for all. }\end{array}$ \\
\hline UN_SDG_5 & Gender equality & Achieve gender equality and empower all women and girls. \\
\hline UN_SDG_6 & Clean water and sanitation & $\begin{array}{l}\text { Ensure availability and sustainable management of water and } \\
\text { sanitation for all. }\end{array}$ \\
\hline UN_SDG_7 & $\begin{array}{l}\text { Affordable and clean } \\
\text { energy }\end{array}$ & $\begin{array}{l}\text { Ensure access to affordable, reliable, sustainable, and modern } \\
\text { energy for all. }\end{array}$ \\
\hline UN_SDG_8 & $\begin{array}{l}\text { Decent work and } \\
\text { economic growth }\end{array}$ & $\begin{array}{l}\text { Promote sustained, inclusive, and sustainable economic } \\
\text { growth, full and productive employment, and decent work for } \\
\text { all. }\end{array}$ \\
\hline UN_SDG_9 & $\begin{array}{l}\text { Industry, innovation, and } \\
\text { infrastructure }\end{array}$ & $\begin{array}{l}\text { Build resilient infrastructure, promote inclusive and sustainable } \\
\text { industrialisation and foster innovation. }\end{array}$ \\
\hline UN_SDG_10 & Reduced inequalities & Reduce inequality within and among countries. \\
\hline UN_SDG_11 & $\begin{array}{l}\text { Sustainable cities and } \\
\text { communities }\end{array}$ & $\begin{array}{l}\text { Make cities and human settlements inclusive, safe, resilient, } \\
\text { and sustainable. }\end{array}$ \\
\hline UN_SDG_12 & $\begin{array}{l}\text { Responsible consumption } \\
\text { and production }\end{array}$ & Ensure sustainable consumption and production patterns. \\
\hline UN_SDG_13 & Climate action & Take urgent action to combat climate change and its impacts. \\
\hline UN_SDG_14 & Life below water & $\begin{array}{l}\text { Conserve and sustainably use the oceans, seas, and marine } \\
\text { resources for sustainable development. }\end{array}$ \\
\hline UN_SDG_15 & $\begin{array}{l}\text { Life on land degradation } \\
\text { and halt biodiversity loss. }\end{array}$ & $\begin{array}{l}\text { Protect, restore, and promote sustainable use of terrestrial } \\
\text { ecosystems, sustainably manage forests, combat desertification, } \\
\text { and halt and reserve land }\end{array}$ \\
\hline UN_SDG_16 & $\begin{array}{l}\text { Peace, justice, and strong } \\
\text { institutions }\end{array}$ & $\begin{array}{l}\text { Promote peaceful and inclusive societies for sustainable } \\
\text { development; provide access to justice for all and build } \\
\text { effective, accountable, and inclusive institutions at all levels. }\end{array}$ \\
\hline UN_SDG_17 & Partnership for the goals & $\begin{array}{l}\text { Strengthen the means of implementation and revitalise the } \\
\text { global Partnership for Sustainable Development }\end{array}$ \\
\hline
\end{tabular}

Source: Pwn elaboration, from UN report, The 2030 Agenda for Sustainable Development

The most recent Sustainable Development Goals Summit was held in October 2019. Progress on the 2030 Agenda for Sustainable Development was reviewed. The report of the Secretary-General on SDG Progress 2019
Special Edition showed that there is adequate progress in some areas, but in many areas, progress is slow. As a follow up to the summit, a request was made to the Secretary-General to issue reports on progress towards the goals, prior 
to the 75 th anniversary of the $\mathrm{UN}$, to engage governments, civil society, the private sector and other stakeholders to generate solutions and accelerate their actions for the 2030 Agenda in the upcoming decade.

\section{Dimensions of the Sustainability concept}

Sustainable development looks into the implementation of strategies to achieve the society that integrate people, planet, and development, instead of looking at the short term for the interests of the few (Lozano, Lozano, Mulder, Huisingh \& Waas, 2013). To understand sustainability, much of the literature tries to base it on a number of different interconnected and interdependent pillars, representing several disciplinary categories. There are authors that advocate two pillars, normally the ecological and socioeconomic aspects, based on the Brundtland Commission (Gibson, 2001); while others advocate three pillars, the ecological, social and economic aspects (Barbier, 1987; Kuhlman \& Farrington, 2010; Waas et al., 2011). Also, there are authors that define four pillars: the social, cultural, economic and environmental challenges (Mader, et al., 2013; Nejati \& Nejati, 2013); or even five pillars, which implies identifying improvements and avoiding damages on ecological, social, economic, cultural and political conditions (Gibson, 2001).

The model presented in Campbell's "planning triangle" in 1996 perceives three main priorities for urban planning: Equity and social justice, economic growth, and environmental protection. Campbell (1996) argues that planners work towards their objectives in the corners of the triangle, while sustainable development is located at the centre. The centre cannot be reached directly. To do so, planners must redefine the term of sustainability, and emphasise the need to think holistically, while establishing a shared language between the three interested parts.

Currently, "sustainability" is almost always seen in terms of three dimensions: social, economic, and environmental. And following Kuhlman and Farrington, (2010) it must be added that all three must be in harmony. Three circles diagram model, described as the "common three-ring sector view of sustainable development" was presented by Giddings, Hopwood, and O'Brien (2002).

The popular three intersecting circles diagram with overall sustainability at the centre appears to have been first presented by Barbier (1987), although it is focused on developing nations, with a different interpretation to the modern one. Nowhere has a theoretical description of the three pillars been found, an absence that frustrates approaches towards a theoretical and operationalised concept of "sustainability" (Purvis, Mao \& Robinson, 2019). There exist different depictions to give a visual understanding and description of the three pillars of sustainability in academic literature. The "Venn diagram" is the dominant interpretation, but according to Purvis et al. (2019), it lacks the strict logical properties of such a construction. The conceptualisation of the pillars does not give a comprehensive understanding of sustainability as Thompson (2017) said.

The representation of the "four pillars sustainability model" is presented as a process of change. It considers the economic, environmental, social and the institutional dimensions. The last dimension is also called democracy or governance, which in the field of political science includes organisations, mechanisms and orientations (Valentin \& Spangenberg, 2000); and the process of merging the environmental aspect and economics to comply with the common interest through public participation (Waas et al., 2011).

Another alternative proposed is a list of changes in the form of principles needed in human actions to achieve progress towards human well-being. The seven points could be reorganised differently, according to the approach and main factors to be addressed (Gibson, 2001).

1. Integrity: Build human-ecological relations to maintain the integrity of biophysical systems in order to maintain the 
irreplaceable life support functions upon which human well-being depends.

2. Sufficiency and opportunity: Ensure that everyone has enough for a decent life and that everyone has the opportunity to seek improvements in ways that do not compromise future generations' possibilities for sufficiency and opportunity.

3. Equity: Ensure that sufficiency and effective choices for all are pursued in ways that reduce dangerous gaps in sufficiency and opportunity (and health, security, social recognition, political influence, etc.) between the rich and the poor.

4. Efficiency: Reduce overall material and energy demands and other stresses on socioecological systems.

5. Democracy and civility: Build our capacity to apply sustainability principles through a better informed and better integrated package of administrative, market, customary and personal decision-making practices.

6. Precaution: Respect uncertainty, avoid even poorly understood risks of serious or irreversible damage to the foundations for sustainability, design for surprise, and manage for adaptation/

7. Immediate and long-term integration: Apply all principles of sustainability at once, seeking mutually supportive benefits.

Other perspectives differentiate between "weak" and "strong" sustainability (Pearce, Markandya \& Barbier, 1989). According to Kuhlman and Farrington, (2010) weak sustainability is defined as heritage for future generations, which includes environmental assets of wealth and capital generated by man, no less than those inherited by the previous generation, while, strong sustainability includes just environmental assets.

From another point of view, Mebratu (1998) focused on three dimension classification for the concept of sustainability. According to this author, it can be developed in three different groups depending on the constituent representation reflected in their presentation: the institutional version, the ideological version, and the academic version. All definitions included in this classification accept that the world is facing an environmental crisis, and that there is a need to make a change to overcome the crisis. Focusing on the academic version, the author identifies three conceptualisations: the economist, the ecologist and the sociologist, showing the scientific community's response to the challenges presented by the environmental crisis of the last century.

A predominant view in literature tries to find links and interdependencies between the different categories or pillars that normally classify sustainability. Unfortunately, outside the academic world, there is a deeply rooted opinion that the interests of the economic and the ecological pillars are opposite. Therefore, there is also an approach in which sustainability is classified according to pillars with competing objectives (Gibson, 2001).

Currently, most contemporary literature on sustainability focuses on the diversity of SDGs established by the UN, and the three sustainability pillars that were explicitly incorporated in this Agency's report in 2012, (Purvis et al., 2019). It is hard to find a theoretical description of the three pillars of sustainability. Purvis et al. (2019) showed that the fundamental concept of the model is not clear and there is no unique source to create such a model.

One of the members of the 1997 World Commission on Environment and Development (WCED) elaborated a report from his point of view, with the updates from the "Brundtland Report". Hauff (2007), 20 years later, explained that during these years, the main fault was not paying attention to the management and measurement aspects of sustainability. The author identifies two management cultures. The first is in the private sector, where corporate responsibility performance has been a key element for improving sustainability, using reports, supply chain management, and sustainability index, tools and best practices that 
improve the organisational learning processes. And the other is the public sector, where sustainability has improved with the use of instruments and tools, such as quantified targets, indicators, national sustainability strategies, and independent national councils for sustainable development, although in the author's opinion, the private sector is far ahead of the public sector.

Among sustainability reports, there is a variety that can be differentiated by stakeholders' influence on corporate operations. The Global Reporting Initiative (GRI) and UN Global Compact 2017 offer guidelines to measure firms' sustainability performance and introduce the SDGs into corporate sustainability reports, although there is still room for improvements on the incorporation of the UN SDGs into strategic business management (Tsalis, Malamateniou, Koulouriotis \& Nikolaou, 2020). Third sector organisations and the public sector have not assumed the SR as the private sector has, which signifies that there is opportunity to improve their implementation by taking into account the GRI reports already in practice in the private sector (Dumay, Guthrie \& Farneti, 2010). Also, there are existing tools and frameworks that can be used in different stages of strategic management, some of which align with defining the problem and setting goals. Only a small number of them help organisations to redefine their business models to be aligned with the SDGs, and none are involved with actual strategic development, but rather only in the latest phases. Therefore, organisations are not likely to carry out the needed transformative changes to implement strategic actions and make an impact towards the SDGs and a more sustainable future (GraingerBrown \& Malekpour, 2019).

In conclusion, since the conception of sustainability, the academic world has tried to give a graphic vision of the dimensions of the concept and how these dimensions influence one another. For companies, working on the reports and guidelines to help them introduce the SDGs into their own strategic sustainability management is key.

\section{The Concept of Corporate Sustainability}

According to the Special Edition of the Report of the Secretary-General on SDG Progress 2019 (United Nations, 2019), there has been a strong mobilisation among many businesses that are making efforts to implement the SDGs. The sustainability development challenge is possible thanks to the participation of the companies (Barkemeyer, Holt, Preuss \& Tsang, 2014). Likewise, it is a guarantee to keep their longlived success (Redman, 2018). According to the details included in the report, specifically, 80 per cent of the member companies of the UN Global Compact have taken actions to advance the goals. They have noted that best practices and models are needed to scale up engagement. The way that the private sector is implementing the goals is through CSR in its firms (Hauff, 2007).

The decade of the 1950s marked a milestone for the definition of CSR in the "modern era" and Howard Bowen was considered the father of CSR due to his book Social Responsibilities of the Businessman (1953), according to Carroll (1999). Within the multiple CSR definitions, the one proposed by Carroll in 1991 is among the most frequently referenced by researchers, according to El-Bassiouny, Darrag, and Zahran, (2018), which is: "The total CSR of business entails the simultaneous fulfilment of the firm's economic, legal, ethical, and philanthropic responsibilities. Stated in more pragmatic and managerial terms, the CSR should strive to make a profit, obey the law, be ethical, and be a good corporate citizen." Carroll, 12 years before, in 1979, articulated a Corporate Social Performance Model, which is still widely used among CSR scholars (Arli \& Lasmono, 2010). The model comprises a conceptual framework that includes the definitions of social responsibility until then. The framework incorporates three different aspects: assessment of a firm's social responsibilities, identification of the social issues that need to be addressed, and the election of the response philosophy. It highlights that all obligations that firms have to society should be considered as social responsibilities, classifying them as economic, legal, ethical and discretionary. 
According to Waddock, (2004), "CSR is the subset of corporate responsibilities that deals with a company's voluntary/discretionary relationships with its societal and community stakeholders." It normally operates with the intention of improving an important aspect of society or relationships with communities or non-governmental organisations (NGOs) (nonprofits). CSR is frequently operationalised as community relations, philanthropic, multi-sector collaboration, or volunteer activities. It falls into what Carroll (1979) termed the discretionary and ethical responsibilities of business. Then, transposing the Brundtland (1987) definition, CSR can be understood as satisfying the needs of stakeholders and maintaining the capacity to satisfy future stakeholders' needs (Dyllick \& Hockerts, 2002). Although in the absence of a common CSR definition, the majority is based on the idea of how companies operate and the way they take into account their economic, social and environmental impacts (Arli \& Lasmono, 2010).

The definition of CSR given by the European Commision (2001) is about the voluntary integration by companies of their social and environmental concerns in their business operations and in their interaction with stakeholders, providing the basis of an integrated approach that combines economic, environmental and social interests to their benefit. Also, it initiates a way of managing change and of reconciling social development with improved competitiveness. The updated definition given in 2011 states that "the responsibility of enterprises for their impacts on society" (European Commission, 2011), thus offering opportunities to reflect on the configuration of organisations as a key element to promote a shift towards a more sustainable economy. The text also highlights the need for companies to implement processes aimed at integrating social, environmental and ethical considerations into their operations and strategy, as well as aspects related to human rights and consumer interests through an approach that contributes to the welfare of society in the long term (Ruiz, Pérez \& Fenech, 2013).
Most researchers analyse the definition of CSR from different perspectives that range from the firm's competitiveness, legitimacy, corporate reputation or environmental sustainability, with the last one being the most researched (Kaymak \& Bektas, 2017).

According to Porter and Kramer (2006), CSR will become increasingly important to firms' competitive success, therefore companies can use their resources and experience to identify and solve social problems while obtaining the best competitive advantage and, at the same time, have a greater impact on the social good. While a company cannot be involved in all aspects of social development because it would be limited, it can, nonetheless, be involved in some, and make its products or services more attractive and the company more profitable. Implementing CSR will increase costs, but probably the benefits outweigh those costs in the long term (Hopkins, 2004). Those companies that voluntarily adopt sustainability policies are more long-term oriented, both in the stock market, as well as in accounting performances. They show higher measurement and disclosure of non-financial information, and executive compensation incentives are linked to sustainability metrics (Eccles, Ioannou \& Serafeim, 2014).

From a legitimacy perspective, CSR is one strategy that provides a positive relationship between the social legitimacy of a company and its business results, and is thus a key element for the competitive advantage of organisations that want to achieve goals consistent with societal values and obtaining resources that are scarce (Díez Martín, Blanco González, Cruz Suárez \& Prado Roman, 2014). In some cases, consumers show that they are skeptical as to why companies are implementing CSR initiatives, either for profits or ethics. Legitimacy theories recognise CSR communication practices as a method to reduce the gap of information between managers and stakeholders, so firms need to invest in it to establish trust (El-Bassiouny et al., 2018). One of the main communication tools that companies use for corporate legitimacy are sustainability 
reports (Miotto \& Vilajoana-Alejandre, 2019). In the same way, legitimacy may affect the decision of managers as to whether to implement sustainability in an organisation (Thomas \& Lamm, 2012).

Porter and Kramer (2003) advocate the reputation approach through an interesting comparison within the business world. They compared the term corporate philanthropy with CSR, which often creates confusion. They assert that nowadays, CSR is applied in a defensive manner to minimise perception of abuses or harm created by firms, while corporate philanthropy uses company resources to create and maximise social value, thereby building the company's reputation instead of using philanthropy to burnish the company's image.

And finally, CSR is the key dimension to the environmental sustainability approach that includes environmental aspects, such as protecting the environment and increasing the environmental performance within the organisational activities (Baumgartner, 2014). From this perspective, solid environmental management provides an ethical and legal component, as well as increasing the firm's value (Kaymak \& Bektas, 2017).

All of these approaches emphasise that CSR is a very important factor for the companies' competitive success. CSR creates a competitive advantage that positively impacts business results (Simanaviciene, Kontautiene \& Simanavicius, 2017; Tien \& Hung Anh, 2018; Rakhmawati, Kusumawati, Rahardjo \& Muhammad, 2020). Likewise, CSR generates a greater social good, which despite increasing costs, the benefits will outweigh it. Therefore, CSR is implemented to mitigate harm created by firms and, at the same time, improve their value.

According to Hussain, (1999), as in Blum-Kusterer and Hussain (2001), the CSR literature documents reasons why a firm should or should not engage in the process of CSR implementation (e.g. green niche markets, pollution prevention pays, stakeholder responsibility and management), but there is little analysis of the relative strengths and there is currently an open debate on the incentives (and disincentives) for actual change. Therefore, a majority of authors are in favour of companies implementing CSR policies, but there are also some who are against it, such as Hayek (1969) and Friedman (1970), (Escamilla-Solano, PlazaCasado \& Flores-Ureba, 2016).

\section{Change Management and Sustainability}

Companies today are immersed in a complex environment and are searching continually for competitive advantages that help them adapt to changing situations. $\mathrm{CM}$ is necessary for companies to meet current sustainability challenges and key to gaining competitive advantages that lead to organisational success (Al-Haddad \& Kotnour, 2015; Todnem, 2008).

The concept of CM was introduced in academic literature by Cleland (1967). He analysed the new figure of project managers that was appearing in organisations at the time, although the pioneer in the field of CM is Kurt Lewin (1890-1947), who is considered the creator of the "three step change model". Lewin's three main elements, field theory, group dynamics and research for action- provide a planned approach to change.

Recently, in literature, the concept of CM has been related to global environmental change mainly due to the assessment reports of the Intergovernmental Panel on Climate Change (IPCC). The acceptance of the concept has evolved to "adaptation", arising as the only viable option for promoting climate change policy (Bassett and Fogelman, 2013). It has been associated with development, highlighting that it is essential to incorporate adaptation in development planning to reduce risk and vulnerability to climate change and social development (Schipper, 2009; Brondoni, Bosetti, \& Civera, 2020). In this way, humankind has, on one hand, the capacity to destroy life on earth, but on the other hand, the capacity to safeguard the environment and improve living conditions for all people on earth (Hauff, 2007). 
There have been two types of organizational development theories according to Woodman, (1989), as cited by Angell and Rands (1998): change process theories and implementation theories. The former describes the dynamics that causes the change, and the latter is oriented to professionals who focus on key factors that lead to change. The process of change also considers both intra-firm and external incentives that promote change, (Blum-Kusterer \& Hussain, 2001). There is a proliferation of ways to classify the types of changes. For example, from the point of view of Blum-Kusterer and Hussain, (2001), change can be incremental, strategic or transformative. According to Bartunek and Moch (1987), it can be first-, second- and thirdorder changes. These authors also discuss the relationship between organisational change and cognitive framework into the practice of organisational development, where the difference depends on the modification of behavioural values that are needed to carry out the change. Multiple theories aim to understand and explain individual, group and organisational change, from the social, psychological, organisational or economical sciences. However, currently there is no research that explains all change approaches in a unified way (Nyström, Höög, Garvare, Weinehall \& Ivarsson, 2013). The only affirmation recognised recently is that one or two methods of change are not sufficient for taking on all of today's different situations in organisations (Burnes \& Jackson, 2011).

$\mathrm{CM}$ is necessary for companies to face the current challenges of sustainable development. One of the three things identified by Gibson (2001) that helps sustainability emerge is a focus on strategies for change, aside from a critique, and a set of principles implying positive objectives. Therefore, today's organisations should change, and how implementation and organisational change are managed is key to increasing the sustainability advantage. Nowadays, one of the main priorities for firms is to adjust their business operations and strategies to the SDGs (Tsalis et al., 2020). In fact, the business sector has a crucial role in the application of SDGs (Arnold, 2018). Individual businesses and organisations from the private sector have a special interest in applying SDGs, and integrating sustainability to guarantee their own long term success (Redman, 2018).

Companies are the main resources in an economy, and this explains the increasing importance of studies on their sustainability (Chang et al., 2017). Large corporations concentrate more power than weaker countries, and they are also able to facilitate or slow the transition to a sustainable society (Brown, 1981). On the other hand, small- and medium-sized enterprise (SMEs), leaning on sustainability, can provide opportunities for growth. Their subsistence is a key factor, even more when their efforts are focused on generating employment, protecting the environment, and reducing their environmental impact (Ruiz et al., 2013). SMEs, as well as non-governmental organisations, are actors that boost social engagement, whereas multinational enterprises use institutional voids as drivers to develop new inclusive business models and invest in education, training, and health services to improve their employees' capabilities (Arnold, 2018).

Although there is a gap in the literature on innovation processes related to sustainability in organisations, there are different proposals for what generic steps organisations have to follow to become sustainable and increase their company's sustainability advantage. The suggestion by Rigby and Tager (2008) contemplates the following steps: the leaders of a company should determine a vision, evaluate existing operations, maximise growth opportunities and measure results to determine the level of success of the company. Likewise, all planned change interventions have a common aim to maximise organisational effectiveness, (Wesselink \& Osagie, 2020) although when assessed less rigorously, they are more likely to be considered successful (Woodman, 2014).

To make changes in organisations, there needs to be a new vision and ethics that imply a structural change in the contexts, that is, a theoretical body on sustainable development Mebratu, (1998). Millar et al. (2012) take this 
further. They propose that leaders need to ensure that they achieve the vision of their organisations, with the guarantee that the actions required are taken to achieve this aim by including them as promoters of thinking for change and the attitude for implementing and organising the change demanded by the sustainability agenda. For that reason, socially responsible leaders have to develop a new way of thinking in times of change; they need to learn how to operate through the complexity and ambiguity of the environment in which their organisations operate and question existing models of business behaviour with respect to sustainability (Van Velsor, Hind, Wilson \& Lenssen, 2009). Furthermore, to raise the success of the change over a period in the organisational context requires planning and managing critical factors (Al-Haddad \& Kotnour, 2015), specifically those that influence resistance towards change (Michel, Todnem \& Burnes, 2013). People and their feelings need to be considered as well (Nyström et al., 2013) because being prepared for individual change in organisations, a positive attitude and organisational commitment are key outcomes (Rafferty, Jimmieson, \& Armenakis, 2013).

Besides, the reciprocal supportive relationship between sustainability reports by the companies and organisational CM is necessary. This relationship has been analysed through a study conducted on 91 companies by the Global Reporting Initiative's Sustainability Disclosure Database in 2013. When a company decides to create and publish a sustainability report, it generates a starting point to plan organisational change in sustainability. It promotes changes within the company, and makes those changes part of the organisation until the publication of a follow-up report (Lozano, Nummert, \& Ceulemans, 2016). Also, higher quality sustainability reporting is associated with a higher opinion of a firm among stakeholders, which signifies that reporting helps enhance legitimacy and access to resources (Kaymak \& Bektas, 2017).

\section{Conclusion and Future Propositions}

Nowadays, companies operate in a challenging and complex, changing environment. Good management of implementing sustainability within their business models and practices is one of the main strategic differentiators that provide a competitive advantage.

As it has been revealed throughout this paper, the concepts of sustainability, CSR and CM have had a long and diverse history in academic literature. The UN has been the principal initiator and driver of sustainable development at the international level. Its milestone dates of key conferences, conventions and summits give insights into the evolution and history of the terms. Sustainability is a point of reference to the adaptation of CSR in organisations.

Even though there are different opinions regarding the pillars that underpin "sustainability", the most current accepted criteria are the ones defined by the Brundtland Commission. It is seen in terms of three criteria: social, economic and environmental terms, and they must be in harmony. Moreover, the United Nations established 17 SDGs in its 2015 summit "Transforming Our World: The 2030 Agenda for Sustainable Development”. Hence, how companies embed those development goals within their business models, strategies and policies is crucial to understanding the achievements realised. To overcome this challenge, firms develop and implement CSR strategies.

Many of the member companies of the UN Global Compact have taken actions to advance the SDGs, but there remains a gap that needs to be addressed through increased implementation of best practices and models, and through improved engagement by companies. In this sense, this sector has a crucial role in the application and integration of sustainability for its own longterm success. Because one of the main priorities for firms is to adjust their business operations and strategies to align with the SDGs, CSR is a very important factor for their success as it 
creates a competitive advantage that positively impacts their business results. Those firms that voluntarily adopt sustainability policies, and are involved in some aspects of social development, are making their products or services more attractive to clients and consumers. In addition, these companies are both more profitable and more long-term oriented. Furthermore, CSR helps to protect a company's reputation, mitigating any unforeseen damage or harm.

CSR also results in a positive relationship between the social legitimacy of a company and its business results. A company that successfully implements a CSR strategy tends to observe improvements in its legitimacy and, therefore, its business performance. Also, legitimacy may affect the decision of managers as to whether to implement sustainability in the organisation. Thus, CSR is a key element for the competitive advantage of organisations that want to achieve goals consistent with societal values. Furthermore, CSR is the key dimension to the environmental sustainability approach. A solid environmental management approach provides an ethical and legal component that increases the firm's value. Implementing CSR as a strategy involves a series of changes not only at the managerial level, but also at the strategic level according to stakeholders' interests. Thus, efficient $\mathrm{CM}$ can maximise the chances of success in this process. A starting point for a company is when it decides to create and publish a sustainability report, because it generates a planned organisational change in sustainability, promoting changes within the company, and making those changes part of the organisation until the publication of a follow-up report. In conclusion, $\mathrm{CM}$ is necessary for companies to meet the current sustainability challenge within their CSR strategies.

This framework creates opportunities for future research, such as an empirical study to analyse how companies manage the change of implementing and evolving the different sustainable goals within their CSR strategies. This would involve the identification and development of models that encompass and facilitate the understanding of the complexity that organisations face in the present time when managing a change. A good option would be to analyse the CSR reports published by companies of a particular sector or to review changing performance indicators over the years.

\section{Acknowledgements}

Authors wished to thank the reviewers and editors for the constructive comments.

\section{References}

Al-Haddad, S., \& Kotnour, T. (2015). Integrating the organizational change literature: A model for successful change. Journal of Organizational Change Management, 28(2), 234-262.

Angell, L. C., \& Rands, G. P. (1998). Toward a process framework of environmental change. Organizations and the Natural Environment Interest Group, 1998 Academy of Management Meeting, San Diego, CA.

Arli, D. I., \& Lasmono, H. K. (2010). Consumers' perception of corporate social responsibility in a developing country. International Journal of Consumer Studies, 34(1), 46-51.

Arnold, M. G. (2018). Sustainability value creation in frugal contexts to foster Sustainable Development Goals. Business Strategy \& Development, 1(4), 265-275.

Barbier, E. B. (1987). The concept of sustainable economic development. Environmental Conservation1, 14(2), 101-110.

Barkemeyer, R., Holt, D., Preuss, L., \& Tsang, S. (2014). What happened to the 'development' in sustainable development? Business guidelines two decades after Brundtland. Sustain Dev. Sustainable Development, 22(1), 15-32.

Bartunek, J. M., \& Moch, M. K. (1987). Firstorder, second-order, and third-order change and organization development 
interventions: A cognitive approach. The Journal of Applied Behavioral Science, 23(4), 483-500.

Bassett, T. J., \& Fogelman, C. (2013). Deja vu or something new The adaptation concept in the climate change literature. Geoforum, 48, 42-53.

Baumgartner, R. J. (2014). Managing corporate sustainability and CSR: A conceptual framework combining values, strategies and instruments contributing to sustainable development. Corporate Social Responsibility and Environmental Management, 21(5), 258-271.

Blum-Kusterer, M., \& Hussain, S. S. (2001). Innovation and corporate sustainability: An investigation into the process of change in the pharmaceuticals industry. Business Strategy and the Environment, 10(5), 300316.

Brondoni, S. M., Bosetti, L., \& Civera, C. (2020). Ouverture de 'CSR and multistakeholder management.' Symphonya. Emerging Issues in Management, 1, 1-15.

Brown, L. R. (1981). Building a sustainable society. WW Norton \& Company, Inc., 500 Fifth Avenue, New York, NY 10110.

Brundtland. (1987). Our Common Future. World Commission on Environment and Development: Brussels.

Burnes, B., \& Jackson, P. (2011). Success and failure in organizational change: An exploration of the role of values. Journal of Change Management, 11(2), 133-162.

Caldwell, L. K. (1984). Political aspects of ecologically sustainable development. Environmental Conservation, 11(4), 299308.

Campbell, S. (1996). Green cities, growing cities, just cities?: Urban planning and the contradictions of sustainable development. Journal of the American Planning Association, 62(3), 296-312.
Carroll, A. B. (1979). A three-dimensional conceptual model of corporate social performance. Academy of Management Review, 4(4), 497-505.

Carroll, A. B. (1999). Corporate social responsibility evolution of a definitional construct. Business \& Society, 38(3), 268295.

Chang, R. D., Zuo, J., Zhao, Z. Y., Zillante, G., Gan, X. L., \& Soebarto, V. (2017). Evolving theories of sustainability and firms: History, future directions and implications for renewable energy research. Renewable and Sustainable Energy Reviews, 72, 48-56.

Cleland, D. I. (1967). Understanding project authority. Business Horizons, 10(1), 63.

Cohen, S., Demeritt, D., Robinson, J., \& Rothman, D. (1998). Climate change and sustainable development: Towards dialogue. Global Environmental Change, 8(4), 341-371.

Daly, H. E. (1996). Beyond growth: The economics of sustainable development. Beacon Press.

Díez Martín, F., Blanco González, A., Cruz Suárez, A., \& Prado Roman, C. (2014). Efecto de la Responsabilidad Social Empresarial sobre la Legitimidad de las Empresas. Anuario Jurídico y Económico Escurialense, 47, 325-348.

Dumay, J., Guthrie, J., \& Farneti, F. (2010). GRI sustainability reporting guidelines for public and third sector organizations: A critical review. Public Management Review, 12(4), 531-548.

Dyllick, T., \& Hockerts, K. (2002). Beyond the business case for corporate sustainability. Business Strategy and the Environment, 11(2), 130-141.

Eccles, R. G., Ioannou, I., \& Serafeim, G. (2014). The impact of corporate sustainability on organizational processes and performance. Management Science, 60(11), 2835-2857. 
El-Bassiouny, N., Darrag, M., \& Zahran, N. (2018). Corporate Social Responsibility (CSR) communication patterns in an emerging market. Journal of Organizational Change Management.

European., C. (2001). Green Paper. Promoting a European framework for Corporate Social Responsibility. https://ec.europa. eu/commission/presscorner/detail/en/ DOC_01_9

European., C. (2011). A renewed EU strategy 2011-14 for Corporate Social Responsibility. https://www.europarl.europa.eu/ meetdocs/2009 2014/documents/com/com com(2011)0681_/com_com(2011)0681_ en.pdf

Friedman, M. (1970). A Friedman doctrine: The social responsibility of business is to increase its profits. The New York Times Magazine, 13(1970), 32-33.

Gibson, R. B. (2001). Specification of sustainability-based environmental assessment decision criteria and implications for determining "Significance" in environmental assessment. Ottawa: Canadian Environmental Assessment Agency.

Giddings, B., Hopwood, B., \& O'brien, G. (2002). Environment, economy and society: Fitting them together into sustainable development. Sustainable Development, 10(4), 187-196.

Goldin, I., \& Winters, A. (1995). Economic policies for sustainable development. The Economics of Sustainable Development, 1-15. Cambridge: Cambridge University Press.

Grainger-Brown, J., \& Malekpour, S. (2019). Implementing the sustainable development goals: A review of strategic tools and frameworks available to organisations. Sustainability, 11(5), 1381.

Guijarro, F., \& Poyatos, J. A. (2018). Designing a sustainable development goal index through a goal programming model: The
Case of EU-28 Countries. Sustainability, 10(9), 3167.

Hauff, V. (2007). Brundtland Report: A 20 years update. In Keynote Speech Presented at the European Sustainability: Linking Policies, Implementation, and Civil Society Action Conference. Berlin, 7.

Hayek, F. A. (1969). The corporation in a democratic society: In whose interest ought it and will it be run. Business Strategy, 225.

Hopkins, M. (2004). Corporate social responsibility: An issues paper. Available at SSRN 908181.

Hussain, S. S. (1999). The ethics of 'going green': The corporate social responsibility debate. Business Strategy and the Environment, 8(4), 203-210.

Kaymak, T., \&Bektas, E.(2017). Corporate social responsibility and governance: Information disclosure in multinational corporations. Corporate Social Responsibility and Environmental Management, 24(6), 555569.

Keating, M. (1993). The Earth Summit's agenda for change: A plain language version of Agenda 21 and the other Rio agreements. Geneva: Centre for Our Common Future.

Kirkby, J., O’keef, P., \& Timberlake, L. (1995). Sustainable development: The earthscan reader. London: Earthscan Publications.

Kuhlman, T., \& Farrington, J. (2010). What is Sustainability? Sustainability, 2(11), 34363448 .

Lozano, R., Lozano, F. J., Mulder, K., Huisingh, D., \& Waas, T. (2013). Advancing higher education for sustainable development: International insights and critical reflections. Journal of Cleaner Production.

Lozano, R., Nummert, B., \& Ceulemans, K. (2016). Elucidating the relationship between sustainability reporting and organisational change management for sustainability. Journal of Cleaner Production, 125, 168188. 
Mader, C. (2013). Sustainability process assessment on transformative potentials: the Graz model for integrative development. Journal of Cleaner Production, 49, 54-63.

Mader, C., Scott, G., \& Razak, D. A. (2013). Effective change management, governance and policy for sustainability transformation in higher education. Sustainability Accounting, Management and Policy Journal, 4(3), 264-284.

Mebratu, D. (1998). Sustainability and sustainable development: Historical and conceptual review. Environmental Impact Assessment Review, 18(6), 493-520.

Michel, A., Todnem By, R., \& Burnes, B. (2013). The limitations of dispositional resistance in relation to organizational change. Management Decision, 51(4), 761-780.

Millar, C., Hind, P., \& Magala, S. (2012). Sustainability and the need for change: Organisational change and transformational vision. Journal of Organizational Change Management, 25(4), 489-500.

Miotto, G., \& Vilajoana-Alejandre, S. (2019). Gender equality: A tool for legitimacy in the fast fashion industry. Harvard Deusto Business Research, 8(2), 134-147. https:// doi.org/https://doi.org/10.3926/hdbr.244

Nejati, M., \& Nejati, M. (2013). Assessment of sustainable university factors from the perspective of university students. Journal of Cleaner Production, 48, 101-107.

Nyström, M., Höög, E., Garvare, R., Weinehall, L., \& Ivarsson, A. (2013). Change and learning strategies in large scale change programs: Describing the variation of strategies used in a health promotion program. Journal of Organizational Change Management, 26(6), 1020-1044.

Pearce, D. W., Markandya, A., \& Barbier, E. P. (1989). Blueprint for a Green Economy. London, UK: Earthscan Publications.

Porter, M. E., \& Kramer, M. R. (2003). Corporate philanthropy: Taking the high ground. Foundation Strategy Group, 13.

Porter, M. E., \& Kramer, M. R. (2006). The link between competitive advantage and corporate social responsibility. Harvard Business Review, 84(12), 78-92.

Purvis, B., Mao, Y., \& Robinson, D. (2019). Three pillars of sustainbaility in search of conceptual origins. Sustainability Science, 14(3), 681-695.

Rafferty, A. E., Jimmieson, N. L., \& Armenakis, A. A. (2013). Change readiness: A multilevel review. Journal of Management, 39(1), 110-135.

Rakhmawati, A., Kusumawati, A., Rahardjo, K., \& Muhammad, N. (2020). The role of government regulation on sustainable business and its influences on performance of medium-sized enterprises. Journal of Sustainability Science and Management, 15(2), 162-178.

Redman, A. (2018). Harnessing the Sustainable Development Goals for businesses: A progressive framework for action. Business Strategy \& Development, 1(4), 230-243.

Rigby, D., \& Tager, S. (2008). Learning the advantages of sustainable growth. Strategy \& Leadership., 36(4), 24-28.

Ruiz, C. C., Pérez, E. A., \& Fenech, F. C. (2013). La sostenibilidad y el papel de la contabilidad en la gestión del cambio climático y la ecoinnovación en la pyme. Cuadernos Económicos de ICE, 86.

Schipper, E. L. F. (2009). Meeting at the crossroads?: Exploring the linkages between climate change adaptation and disaster risk reduction. Climate and Development, 1(1), 16-30.

Simanaviciene, Z., Kontautiene, R., \& Simanavicius, A. (2017). Assumptions of Corporate Social responsibility as competitiveness factor. Montenegrin Journal of Economics, 13(3), 149-160.

Solano, S. E., Casado, P. P., \& Ureba, S. F. (2016). Análisis de la divulgación de la información 
sobre la responsabilidad social corporativa en las empresas de transporte público urbano en España. Revista de Contabilidad, 19(2), 195-203. https://doi.org/https://doi. org/10.1016/j.rcsar.2015.05.002

Solow, R. (1992). An almost practical step toward sustainability; An invited lecture on the occasion of the Fourtieth Anniversary of Resources for the Future (No. AV 333.716 no. 13). Resources for the Future, Washington, DC (EUA).

Thomas, T. E., \& Lamm, E. (2012). Legitimacy and organizational sustainability. Journal of Business Ethics, 110(2), 191-203.

Thompson, P. B. (2017). The spirit of the soil: Agriculture and environmental ethics (2nd ed.). Routledge, New York: Taylor \& F.

Tien, N. H., \& Hung Anh, D. B. (2018). Gaining competitive advantage from CSR policy change: case of foreign corporations in Vietnam. Polish Journal of Management Studies, 18.

Todnem By, R. (2008). Organisational change management: A critical review. Journal of Change Management, 5(4), 369-380.

Tsalis, T. A., Malamateniou, K. E., Koulouriotis, D., \& Nikolaou, I. E. (2020). New challenges for corporate sustainability reporting: United Nations' 2030 agenda for sustainable development and the sustainable development goals. Corporate Social Responsibility and Environmental Management.

Tulloch, L. (2013). On science, ecology and environmentalism. Policy Futures in Education, 11(1), 100-114.

United Nations. (1997). Rio+5 Conference, (New York). https:/www.un.org/press/ en/1997/19971105.PI1037.html

United Nations. (2000). Millennium Summit. https://www.un.org/en/events/pastevents/ millennium_summit.shtml

United Nations. (2002). World Summit on Sustainable Development. (Johannesburg). https://sustainabledevelopment.un.org/ milesstones/wssd

United Nations. (2012). Rio+20 Conference "The future we want", (Río Janeiro).

United Nations. (2015). World Summit on Sustainable Development "Transforming our World: The 2030 Agenda for Sustainable Development," (New York). https://www. un.org/sustainabledevelopment/summit/

United Nations. (2019). Report of the SecretaryGeneral on SDG Progress. https:// sustainabledevelopment.un.org/content/ documents/24978Report_of_the_SG_on_ SDG_Progress_2019.pdf

Valentin, A., \& Spangenberg, J. H. (2000). A guide to community sustainability indicators. Environmental Impact Assessment Review, 20(3), 381-392.

Van Velsor, E., Hind, P., Wilson, A., \& Lenssen, G. (2009). Developing leaders for sustainable business. Corporate Governance: The International Journal of Business in Society.

Waas, T., Hugé, J., Verbruggen, A., \& Wright, T. (2011). Sustainable development: A bird's eye view. Sustainability, 3(10), 1637-1661.

Waddock, S. (2004). Parallel universes: Companies, academics, and the progress of corporate citizenship. Business and Society Review, 109(1), 5-42.

WCED, S. W. S. (1987). World commission on environment and development. Our Common Future, 17, 1-91.

Wesselink, R., \& Osagie, E. (2020). Differentiating CSR Managers' roles and competencies: Taking conflicts as a starting point. The Research Handbook of Responsible Management. Cheltenham: Edward Elgar.

Wilderer, P. A. (2007). Sustainable water resource management: The science behind the scene. Sustain. Sci, 2, 1-4.

Woodman, R. W. (1989). Organizational change and development: New arenas for inquiry 
and action. Journal of Management, 15(2), 205-228.

Woodman, R. W. (2014). The science of organizational change and the art of changing organizations. The Journal of Applied Behavioral Science, 50(4), 463477. 